\title{
The relationship between servant leadership, organisational citizenship behaviour and team effectiveness
}

\begin{tabular}{|c|c|}
\hline $\begin{array}{l}\text { Authors: } \\
\text { Bright Mahem } \\
\text { Amos S. Engel }\end{array}$ & $\begin{array}{l}\text { be }^{1} \\
\text { brecht }^{1}\end{array}$ \\
\hline \multicolumn{2}{|c|}{$\begin{array}{l}\text { Affiliations: } \\
{ }^{1} \text { Department of Industrial } \\
\text { Psychology, Stellenbosch } \\
\text { University, South Africa }\end{array}$} \\
\hline \multicolumn{2}{|c|}{$\begin{array}{l}\text { Correspondence to: } \\
\text { Bright Mahembe }\end{array}$} \\
\hline \multicolumn{2}{|c|}{$\begin{array}{l}\text { Email: } \\
\text { bmahembe@sun.ac.za }\end{array}$} \\
\hline \multicolumn{2}{|c|}{$\begin{array}{l}\text { Postal address: } \\
\text { Private Bag X01, Matieland, } \\
\text { Stellenbosch 7602, } \\
\text { South Africa }\end{array}$} \\
\hline \multicolumn{2}{|c|}{$\begin{array}{l}\text { Dates: } \\
\text { Received: } 11 \text { Mar. } 2013 \\
\text { Accepted: } 06 \text { Dec. } 2013 \\
\text { Published: } 07 \text { Feb. } 2014\end{array}$} \\
\hline \multicolumn{2}{|c|}{$\begin{array}{l}\text { How to cite this article: } \\
\text { Mahembe, B., \& Engelbrecht, } \\
\text { A.S. (2014). The relationship } \\
\text { between servant leadership, } \\
\text { organisational citizenship } \\
\text { behaviour and team } \\
\text { effectiveness. SA Journal } \\
\text { of Industrial Psychology/SA } \\
\text { Tydskrif vir Bedryfsielkunde, } \\
\text { 40(1), Art. \#1107, } 10 \text { pages. } \\
\text { http://dx.doi.org/10.4102/ } \\
\text { sajip.v40i1.1107 }\end{array}$} \\
\hline \multicolumn{2}{|c|}{$\begin{array}{l}\text { Note: } \\
\text { This article forms part of } \\
\text { a series of articles by the } \\
\text { authors of this article, based } \\
\text { on the notion of servant } \\
\text { leadership. See Mahembe \& } \\
\text { Engelbrecht (2013). }\end{array}$} \\
\hline \multicolumn{2}{|c|}{$\begin{array}{l}\text { Copyright: } \\
\text { (C) 2014. The Authors. } \\
\text { Licensee: AOSIS } \\
\text { OpenJournals. This work } \\
\text { is licensed under the } \\
\text { Creative Commons } \\
\text { Attribution License. }\end{array}$} \\
\hline \multirow{2}{*}{ Read online: } & \\
\hline & $\begin{array}{l}\text { Scan this QR } \\
\text { code with your } \\
\text { smart phone or } \\
\text { mobile device } \\
\text { to read online. }\end{array}$ \\
\hline
\end{tabular}

Orientation: Team effectiveness and organisational citizenship behaviour (OCB) are outcomes vital for team success. Servant leadership practices also play a critical role in team effectiveness and OCB.

Research purpose: The goal of the study was to analyse the relationships between servant leadership, OCB and team effectiveness in the South African school system.

Motivation for the study: The changing nature of leadership, coupled with the increased use of teams, necessitates a study on how follower-focused leadership practices enhance team member effectiveness.

Research approach, design and method: A non-probability sample of 288 teachers was drawn from 38 schools in the Western Cape in South Africa. Item analysis and confirmatory factor analysis were conducted on the data.

Main findings: The team effectiveness and refined servant leadership questionnaires displayed high levels of internal consistency. The organisational citizenship behaviour scale exhibited moderate reliability coefficients. Good fit was found for the structural and measurement models of the latent variables through confirmatory factor analysis and structural equation modelling. Positive relationships were found between servant leadership, team effectiveness and OCB.

Practical/managerial implications: The findings emphasise the role played by servant leadership behaviours in promoting positive behaviours and outcomes for teams. Future studies should develop the theoretical model further, by identifying other variables that influence team effectiveness positively and testing the model using revenue-oriented teams.

Contribution/value-add: Schools today face the challenge of developing strategies for achieving team effectiveness. The servant leadership style recognises and promotes the oneon-one development of followers likely to promote positive outcomes and team effectiveness.

\section{Introduction}

Organisations increasingly utilise teams in order to increase their competitive advantage, improve productivity, enhance creativity, increase response times and improve decision-making (Afolabi, Adesina \& Aigbedion, 2009; Schlechter \& Strauss, 2008; Sheng \& Tian, 2010; Wong, Tjosvold \& Liu, 2009). It can, therefore, be argued that effective team functioning is one of the major determinants of organisational success. Although numerous studies on team effectiveness in organisations exist, little has been done on school teacher teams in public sector organisations.

Public organisations, such as schools, still face the challenge of developing an effective strategy for achieving team effectiveness. The close relationship between successful leadership and effective schools is widely recognised (Bush \& Heystek, 2006). For a school to achieve effectiveness, it is imperative that the leadership skills of principals be developed to enhance the quality of school management and improve educational outcomes. The South African Schools Act of 1996 identifies governance and management as two separate activities led by two overlapping teams. The professional management of the school is the responsibility of the principal and the school management team (Bush \& Heystek, 2006). In a school setting, principals and teachers are the main determining factors of the quality of education (Hallinger \& Heck, 1996; Sisman, 2004). Teachers who carry out educational activities in the class and who spend more time with learners have an important effect on learner academic performance (Rowan et al., 2002). Principals, as leaders, can play a critical role in helping teachers to realise their potential as far as service delivery in the classroom is concerned (Cerit, 2009). One of the leadership approaches that are likely to affect school team effectiveness is servant leadership. 
The practice of servant leadership by the principal enables teachers to work towards a shared vision and honour collective commitments to self and has the potential to improve the entire school environment in which educators work and serve (Cerit, 2009; DuFour, 2001). A serviceoriented leadership approach such as servant leadership is likely to create an environment conducive to effective school team functioning (Irving \& Longbotham, 2007; Morgeson, DeRue \& Karam, 2010; Transcritti, 2010). Generally, the servant leadership approach focuses on developing employees to their fullest potential in the areas of task effectiveness, community stewardship, self-motivation and future leadership capabilities (Greenleaf, 1977).

Servant leadership entails an understanding and practice of leadership that places the good and interests of followers above the self-interest of the leader (Greenleaf, 1977). The servant leader creates opportunities for followers to help them to grow (Luthans \& Avolio, 2003). This is achieved through fostering self-confidence, serving as a role model, inspiring trust and providing information, feedback and resources (Liden, Wayne, Zhao \& Henderson, 2008; Lord, Brown \& Freiberg, 1999). Contrary to traditional bureaucratic and mechanistic leadership styles, principals as servant leaders do not use their power to get things done, but rather use oneon-one communication as well as persuasion to understand the teachers' needs, desires, abilities, goals and potential (Liden et al., 2008; Van Dierendonck \& Nuitjen, 2011). With knowledge of each follower's unique characteristics and interests, leaders then assist followers in achieving their potential (Liden et al., 2008). Servant leadership also stresses personal integrity and focuses on forming strong long-term relationships with teachers and organisational stakeholders such as the community, parents, universities, alumni and employing organisations (Graham, 1991).

Since servant leadership is manifested through developing and empowering followers, by expressing authenticity, humility, interpersonal acceptance and stewardship and by providing guidance, subordinates are likely to feel empowered (Van Dierendonck, 2011). Prior research has demonstrated that employees, when empowered, exude a higher level of self-confidence and have a greater sense of being able to positively influence their work environment (Zhu, May \& Avolio, 2004). Servant leadership is an altruistic leadership style that potentially contributes to the development of positive attitudes in followers, most notably organisational citizenship behaviour (OCB) (Sendjaya, Sarros \& Santorra, 2008).

Organisational citizenship behaviour, as a specific behaviour of a team member, can be understood as a team process variable that has a dynamic impact on team effectiveness (Ren-Tao \& Heung-Gil, 2009). This type of behaviour is important in a team context because it indicates the extent to which individual members of the organisation or team are able and willing to engage in organisational citizenship behaviours that are beneficial to the organisation (OCBO) and other individuals within the organisation (OCBI)
(Mohammad, Habib \& Alias, 2011). Extra-role behaviours are also important and desirable for an organisation, as they are likely to promote more effective communication, which allows best practices to be shared amongst employees or fosters increased coordination amongst employees (Ren-Tao \& Heung-Gil, 2009).

Whilst the literature on teams and servant leadership is growing, no research was found on the relationships between servant leadership, organisational citizenship behaviour and team effectiveness in an educational setting in South Africa. It is important to understand team effectiveness in school settings as it helps to indicate how the nature of the school as a workplace, as well as how the quality of interactions in schools, affect teachers' effectiveness, performance and the portrayal of behaviours that go beyond the call of duty.

\section{Aim of study}

The primary goal of the study was to conduct an analysis of the relationships that exist between servant leadership, organisational citizenship behaviour and school team effectiveness. The secondary goal was to validate a theoretical model explicating the structural relationships between these variables in the South African school system.

\section{Conceptualising team effectiveness}

Team effectiveness refers to the attainment of common goals or objectives through the coordination of team members' work activities (Irving \& Longbotham, 2007). It has significant implications on the team-produced results and in terms of the consequences that the school team has for its teachers (Piccoli, Powell \& Ives, 2004). For school teams to be classified as effective, the team members (teachers) need to produce high quality outputs (academic performance) as well as derive some satisfactory working experience. Consequently, school team effectiveness should measure the performance of schools and the nature of the school team as a working unit, as well as the effect of the school team on its individual teachers (Piccoli et al., 2004).

A review of the literature on teams reveals a high volume of studies geared towards identifying sets of variables that could be used to operationalise team effectiveness (Bettenhausen, 1991; Cohen \& Bailey, 1997; Guzzo, 1986; Hackman, 1987; Neale \& Mannix, 2012; Pina, Martinez \& Martinez, 2008; Ross, Jones \& Adams, 2008). Despite the existence of numerous studies on team effectiveness, researchers face problems with defining the team effectiveness construct (Pina et al., 2008). The problems encountered relate to failure to distinguish between determinant factors and criteria of effectiveness in South African schools. Generally, two models of team effectiveness exist, namely the unidimensional and multidimensional perspectives. The unidimensional view utilises objective measures of team performance (Kolodny \& Kiggundu, 1980; Shea \& Guzzo, 1987) or of the degree of real productivity (Pina et al., 2008). The multidimensional view posits that team effectiveness is a function of several other variables besides performance (Hackman, 1987; Hackman 
\& Walton, 1986; Nieva, Fleishman \& Reick, 1978). In a school setting, team effectiveness can be defined in terms of academic performance and successful extramural activities.

The input-process-output (I-P-O) heuristic formulated by McGrath (1964; cf. Gladstein, 1984; Salas, Dickenson, Converse \& Tannenbaum, 1992; Salas, Stagl \& Burke, 2004; Stagl, Salas \& Burke, 2007) is one of the multidimensional team effectiveness frameworks that have dominated team effectiveness circles over the past four decades (Kozlowski \& Ilgen, 2006). The model encompasses individual-level input factors, such as group (e.g. school team) composition variables (e.g. skills, heterogeneity) and group structure (e.g. formal leadership, work norms). It also incorporates organisational-level input factors, such as resources available (e.g. training, consulting) and organisationalstructure variables (e.g. rewards, supervisory control). The relations between individual-level and organisational-level input factors and team effectiveness are mediated by group processes. The model also shows that group task complexity, uncertainty and interdependence moderate the relations between group processes and outcomes, such as satisfaction (Gladstein, 1984). Processes thus mediate the conversion of inputs to outcomes.

Cohen and Bailey (1997) categorise effectiveness into three major dimensions according to the team's impact: performance effectiveness (e.g. academic performance), attitudinal outcomes (satisfaction, commitment and trust in school leadership) and behavioural outcomes that include absenteeism, turnover and safety.

Ross et al. (2008) improve on the Cohen and Bailey model by adding more dimensions. These authors operationalised team effectiveness in terms of five broad principles contributing to team effectiveness, namely behaviour (team members' perceived behavioural control, conduct and reactions towards others), attitude (team members' feelings of psychological safety, reception of and cooperation with others as well as acceptance of feedback and accountability for their actions), team member style (team members' personal characteristics such as assertiveness and responsiveness), performance and corporate culture (an enabling business climate with adequate resources and support for team members to function) (Hackman, 2002; Ross et al., 2008). Performance comprises the degree to which the output meets the consumers' (e.g. community, parents and learners) standards of quality, quantity and timeliness of academic outcomes. In order to enhance team performance, team members should be guided by a compelling vision which translates into clear, challenging and specific relevant goals to be accomplished (Hackman, 2002; Ross et al., 2008).

\section{Conceptualising servant leadership}

First emerging in the 1970s, the servant leadership concept has its roots in the seminal work of Robert Greenleaf, a prominent businessman who described a people-centred leadership philosophy, one that advocates the servant leader as leader:
It begins with the natural feeling that one wants to serve, to serve first. Then conscious choice brings one to aspire to lead. The difference manifests itself in the care taken by the servant first to make sure that other people's highest priority needs are being served. The best test is: Do those served grow as persons; do they, while being served, become healthier, wiser, freer, more autonomous, more likely themselves to become servants? (Greenleaf, 1970, p. 4)

Servant leadership is not a new construct: it can be traced back to historical leaders such as Mahatma Gandhi, and in more recent times to Mother Theresa, and religious leaders such as Martin Luther King, who practised and upheld it as being the way to approach leadership (Sendjaya \& Sarros, 2002). Despite the existence of a universally accepted definition of servant leadership, the servant-leadership construct has gained considerable popularity mainly over the past 50 years, as evidenced by the large number of practitioneroriented servant-leadership articles on the subject (Barbuto \& Wheeler, 2006; Dannhauser \& Boshoff, 2007; Liden et al., 2008; Parolini, Patterson \& Winston, 2009; Sun \& Wang, 2009; Van Dierendonck, 2011). Most of the studies have focused on how servant leadership influences work behaviour and on the theoretical development and measurement of the servant leadership construct (Barbuto \& Wheeler, 2006; Sendjaya \& Sarros, 2002; Van Dierendonck, 2011).

Servant leadership is based on the premise that, to bring out the best in their followers, leaders rely on one-on-one communication to understand the abilities, needs, desires, goals and potential of their employees. With knowledge of each follower's unique characteristics and interests, leaders then assist followers in achieving their potential. This encouragement is done through building self-confidence (Liden et al., 2008; Lord, Brown \& Freiberg, 1999), serving as a role model, inspiring trust and providing information, feedback and resources. Servant leadership is regarded as virtuous, highly ethical and based on the premise that service to followers is at the core of leadership (Sendjaya et al., 2008). It is important to realise that, according to Greenleaf, the servant-leader is 'primus inter pares' (i.e. first amongst equals), who does not use his or her power to get things done but who tries to persuade and convince staff (Van Dierendonck, 2011). Servant leaders also demonstrate the qualities of altruism, humility, hope, integrity, vision, caring for other people, trustworthiness and interpersonal acceptance (Van Dierendonck, 2011).

\section{Conceptualising organisational citizenship behaviour}

Derived from Katz's (1964) notion of extra-role behaviours, organisational citizenship behaviours (OCBs) have been defined as behaviours displayed by teachers that are discretionary, not directly or explicitly recognised by the formal reward system and that, in the aggregate, promote the effective functioning of an organisation (school). These behaviours are often internally motivated, arising from and sustained by an individual's intrinsic need for a sense of achievement, competence, belonging or affiliation (Organ, 1988). 
There is no consensus in the literature on the number of dimensions of OCB. Researchers have proposed anything from two (Williams \& Anderson, 1991) to seven (Podsakoff, MacKenzie, Paine \& Bachrach, 2000). Organ (1988) originally proposed the following five dimensions: altruism, conscientiousness, sportsmanship, courtesy and civic virtue. According to Organ, sportsmanship refers to an employee's ability to tolerate less-than-ideal circumstances without complaining and making problems seem bigger than they actually are; civic virtue indicates an employee's active interest in the life of the organisation; conscientiousness (often called compliance) indicates an employee's acceptance and adherence to the rules, regulations and procedures of the organisation. Courtesy refers to actions aimed at the prevention of future problems, whilst altruism indicates helping behaviours aimed at specific individuals. Williams and Anderson (1991) categorise OCB into two types: behaviour that is directed at individuals in the organisation (OCBI) and behaviour that is concerned with helping the organisation as a whole (OCBO). Podsakoff et al. (2000) present the seven common themes or dimensions of OCB as: helping behaviour, sportsmanship, organisational loyalty, organisational compliance, individual initiative, civic virtue and self-development. In the current study, Organ's conceptualisation of the extra-role behaviour construct is used.

\section{The relationships between servant leadership, organisational citizenship behaviour and team effectiveness}

The principal's behaviour is a crucial factor in the achievement of school team effectiveness. School leaders' values and interpersonal competencies are of critical importance to the overall success of the school team. A team leader needs to be goal directed, create commitment, give recognition, be able to handle different personality types within the team and enhance cohesiveness amongst team members. All of these aspects are incorporated in servant leadership (Van Dierendonck, 2011). Servant leadership extends beyond the desires of the self-ego and builds a working climate that generates feelings of employee empowerment (Liden et al., 2008). The inspirational and moral component of servant leadership is important for the development of teams. Teachers are more likely to work collaboratively in the achievement of school team goals if they have inspirational and moral confidence in their leader (Van Dierendonck, 2011).

Although numerous studies on the importance of leadership in team performance are available (Gupta, Huang \& Niranjan, 2010; Kuo, 2004; Morgeson, DeRue \& Karam, 2010), the role that servant leadership plays in the effective functioning of school teams has not been studied extensively. Irving and Longbotham (2007) examined the relationship between servant leadership and team effectiveness in a division of an international non-profit-making organisation in the United States. Transcritti (2010) confirmed these findings in a recent study of church pastors in the state of Ohio, by reporting a significant positive relationship between the two concepts. Recently, $\mathrm{Hu}$ and Liden (2011) also found a positive relationship between servant leadership and team effectiveness.

Based on the above theoretical arguments and empirical findings, it was hypothesised that servant leadership has a positive effect on team effectiveness.

Leadership behaviours have been found to be an important predictor of OCB. Previous studies have documented the positive role of leadership styles such as transformational leadership, transactional leadership and leader-member exchange in influencing engagement in OCBs (Alizadeh, Darvishi, Nazari \& Emami, 2012; Davoudi, 2012; Podsakoff et al., 2000; Schlechter \& Engelbrecht, 2006). Despite the rising prominence of servant leadership, only a few studies have reported its influence on organisational citizenship behaviour. The small number of studies recorded to date have found a significant positive relationship between servant leadership and employee OCB (Ehrhart, 2004; Güçel \& Begeç, 2012; Liden et al., 2008; Neubert, Kacmar, Carlson, Chonko \& Roberts, 2008; Vondey, 2010; Walumbwa, Hartnell \& Oke, 2010). These findings are consistent with the fact that, since servant leadership is characterised by a desire on the part of the leader to serve the needs of the followers and ensure that the followers grow wiser by the passing of each day (Greenleaf, 1977; Van Dierendonck, 2011), the followers are likely to reciprocate the leader's humility and empowering development by going the extra mile as far as accomplishing team goals and vision are concerned. Furthermore, servant leaders have been found to be effective because the needs of followers are so looked after that they reach their full potential, and hence perform at their best (McCrimmon, 2010).

Based on the above empirical findings and theoretical arguments, it was hypothesised that servant leadership positively affects OCB.

One of the pioneering studies on organisational citizenship behaviour and team effectiveness was carried out by Karambayya (1990), who concluded that high performance teams are made up of employees who exhibit high organisational citizenship behaviour. Organisational citizenship behaviour contributes to team effectiveness through its impact on the context in which the task is performed (Podsakoff \& MacKenzie, 1997). OCBs are also important and desirable for an organisation, as they are likely to promote more effective communication, which allows best practices to be shared amongst employees, or foster increased coordination amongst employees (Ren-Tao \& Heung-Gil, 2009). These behaviours extend beyond what is required; thus they include efforts that support group cohesion, as well as behaviours that are helpful to task accomplishment (Randel, 2003). Organisations rely on their employees' performance of OCB to help their colleagues with problems, promote a positive work climate, tolerate inconveniences without complaints and protect the organisation's resources (Witt, 1991). 
On the basis of the above theoretical arguments and empirical findings, it was postulated that OCB has a positive effect on team effectiveness.

\section{Theoretical model}

After an in-depth investigation of the literature, a theoretical model was developed. Figure 1 illustrates the theoretical model that depicts the specific hypothesised causal linkages between servant leadership, OCB and team effectiveness.

\section{Statistical hypotheses}

Hypothesis 1: If the overarching substantive research hypothesis is interpreted to indicate that the structural model provides an approximate account of the way in which servant leadership and OCB influence team effectiveness, the substantive research hypothesis translates into the following close fit null hypothesis:

$$
\begin{aligned}
& \mathrm{H}_{01}: \mathrm{RMSEA}<.05 \\
& \mathrm{H}_{\mathrm{a} 1}: \mathrm{RMSEA}>.05
\end{aligned}
$$

RMSEA is the root mean square error of approximation.

The overarching structural model substantive research hypothesis was dissected into three path-specific substantive research hypotheses. These three path-specific research hypotheses translate into the following specific research hypotheses:

Hypothesis 2: Servant leadership $\left(\xi_{1}\right)$ positively affects team effectiveness $\left(\eta_{2}\right)\left(H_{02: \gamma 21}=0 ; H_{\text {a2: } r 21}>0\right)$.

Hypothesis 3: Servant leadership $\left(\xi_{1}\right)$ positively affects OCB $\left(\eta_{1}\right)$ $\left(\mathrm{H}_{03:} \gamma_{11}=0 ; \mathrm{H}_{\mathrm{a3}: \gamma 11}>0\right)$.

Hypothesis 4: OCB $\left(\eta_{1}\right)$ positively affects team effectiveness $\left(\eta_{2}\right)$ $\left(\mathrm{H}_{04:} \beta_{21}=0 ; \mathrm{H}_{\mathrm{a4}:} \beta_{21}>0\right)$.

\section{Research design \\ Research approach}

In order to achieve the set objectives as well as test the hypotheses formulated to answer the research question, a quantitative research design was used. Specifically, the model was tested using structural equation modelling (SEM).

\section{Research procedure}

The participants received a questionnaire that was made up of a covering letter, a biographical section and the three

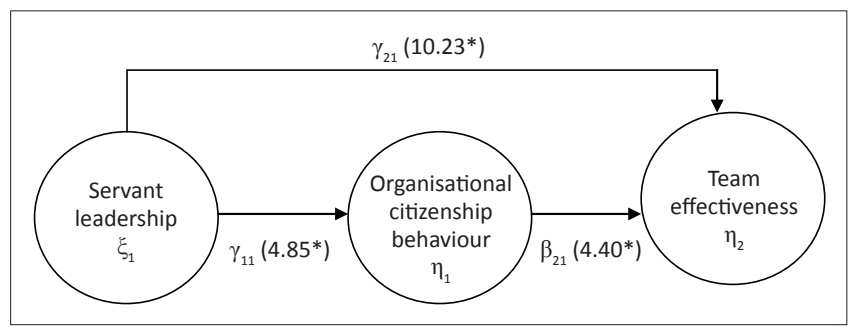

$*, t$-values $\geq|1.96|$ indicate significant path coefficients $(p<0.05)$.

FIGURE 1: The conceptual structural model. measuring instruments. The covering letter highlighted the aim of the study, instructions on completing the questionnaires, as well as the participants' ethical rights.

\section{Research method}

\section{Sample}

A non-probability sampling strategy was used in the study. Although the team is expected to be the unit of analysis in studies of this nature, the present study used the individual team members (teachers) as the unit of analysis. The study was conducted using school teachers drawn from schools in the Western Cape in South Africa. For this reason the hypotheses that have been discussed indicate teachers' perceptions of the different relationships in a school.

The sample consisted of 205 female (71.2\%) and 83 male $(28.8 \%)$ teachers. The majority $(30.9 \%)$ fell within the age category of $41-50$ years. The ethnic distribution in the sample was: Black (17.3\%), mixed-race $(39.6 \%)$ and White $(43.1 \%)$. The home language of the majority was Afrikaans $(74.9 \%)$, with a minority using isiXhosa (12.9\%) and English $(10.4 \%)$ as their home languages. Regarding highest level of qualification, the majority of respondents had a degree or diploma $(92.7 \%)$.

\section{Measuring instruments}

Three self-reporting measuring instruments were identified and used in measuring the constructs under study.

\section{Servant leadership}

The servant leadership of the principal was measured using the servant leadership questionnaire (SLQ) (Barbuto \& Wheeler, 2006). The SLQ was formulated to develop a scale that captures the eleven characteristics of servant leadership. Barbuto and Wheeler (2006), through factor analysis, found only five factors underlying 23 items. Reliabilities for the self and rater versions of the scale ranged from .68 to .87 and .82 to .92 respectively. The rater version of the scale yielded the following coefficient alphas: altruistic calling $(\alpha=.82)$, emotional healing $(\alpha=.91)$, wisdom $(\alpha=.92)$, persuasive mapping $(\alpha=.83)$ and organisational stewardship $(\alpha=.83)$ (Barbuto \& Wheeler, 2006). Example items included: 'This person goes above and beyond the call of duty to meet my needs' (altruistic calling), 'This person is talented at helping me to heal emotionally' (emotional healing), 'This person is good at anticipating the consequences of decisions' (wisdom), 'This person is very persuasive' (persuasive mapping) and 'This person believes that the organisation needs to play a moral role in society' (organisational stewardship).

\section{Organisational citizenship behaviour}

Podsakoff and Mackenzie's (1994) organisational citizenship behaviour scale (OCBS) was used to measure organisational citizenship behaviour. This instrument consists of 24 items measuring five subscales as conceptualised by Organ (1988), namely: altruism, conscientiousness, sportsmanship, courtesy and civic virtue. The OCBS has sound psychometric 
attributes (Hui, Law \& Chen, 1999; Moorman, 1991; Niehoff \& Moorman, 1993). The reliability alpha coefficients for the subscales ranged from (.70 for civic virtue to .85 for altruism. Use of the confirmatory factor analysis according to Podsakoff and MacKenzie confirmed the hypothesised factor structure, with a Tucker-Lewis fit index of .94 ascertaining that all of the items used to assess the five OCB factors loaded significantly on their intended factors. Example items include: 'I help others who have heavy workloads', 'I always find fault with what the organisation is doing', 'I attend meetings that are not mandatory but are considered important', 'I willingly give my time to help others who have work-related problems'.

\section{Team effectiveness questionnaire (TEQ)}

An adapted eleven-item team effectiveness questionnaire (TEQ) developed by Larson and LaFasto (2001) was used to measure school team effectiveness. The TEQ is a selfreporting scale and is based on Larson and LaFasto's earlier grounded theory work that attempted to identify the essential characteristics of effective teams. The Cronbach's alpha coefficient for this questionnaire is .85, which also was found when Dannhauser (2007) administered the TEQ on a South African sample. Example items include: 'Achieving the team goal is a higher priority than any individual objective' and 'The team is given the resources it needs to get the job done'.

\section{Statistical analysis}

Missing values: Self-report instruments are often plagued by the missing values problem. In the present study, this problem was addressed through imputation by matching (Jöreskog \& Sörbom, 2006). In this technique, missing values are substituted by values derived from one or more other cases that had a similar response pattern over a set of matching variables (Jöreskog \& Sörbom, 2006).

Test for multivariate normality: Robust maximum likelihood (RML) estimation was used to estimate the parameters set free in the model because of the lack of multivariate normality in the data (Jöreskog \& Sörbom, 1996; Mels, 2003).

Structural equation modelling: Structural equation modelling (SEM) helps to explain the patterns of covariances found amongst the observed variables in terms of the relationships hypothesised by the measurement and structural models. The structural model describes the relationships between the latent variables themselves whilst the measurement model describes how each latent variable is measured by corresponding manifest indicators (Diamantopoulos \& Siguaw, 2000). In SEM, the implied covariance matrix generated by the model is compared with the observed covariance matrix originally inputted as data to determine model fit (see also Mahembe \& Engelbrecht 2013).

\section{Evaluating the measurement models}

Item analysis was performed to identify any poor items (i.e. corrected-item-total correlations $<0.30$ ) of the questionnaires used in the study using SPSS version 20. After deletion of poor items, LISREL 8.80 (Jöreskog \& Sörbom, 2006) was used to perform confirmatory factor analysis (CFA) on the refined scales. Once a satisfactory fit was achieved, any item with an inadequate completely standardised factor loading $(<0.30)$ was deleted (Hair, Black, Babin, Anderson \& Tatham, 2006). Two items for the SLQ and one item for the TEQ were flagged as problematic and excluded from subsequent analysis.

\section{Trustworthiness}

Reliability: The reliability of each of the instruments used in the study was ensured through the use of the scale reliability analysis procedure available in SPSS, as discussed in the results section.

Validity: Standard measuring instruments were used to measure servant leadership, OCB and team effectiveness. This assisted in maintaining validity. The construct validity of the instruments used was further ensured through the use of confirmatory factor analysis.

\section{Ethical considerations}

In terms of ethics, permission for the research was obtained from the institution's research ethics committee, as well as the Department of Education. Informed consent was sought from the participants before questionnaire completion and confidentiality of the data obtained was maintained. Participants were not obliged to take part in the study and there was no envisaged harm.

\section{Results \\ Missing values}

The use of imputation by matching resulted in an effective sample size of 288 cases (Jöreskog \& Sörbom, 2006).

\section{Goodness-of-fit: The measurement and structural models}

Comparison of the goodness-of-fit indices reported in Table 1 indicates that the structures of the SLQ, OCBS and TEQ present a satisfactory fit with the data (Hair et al., 2006; Kelloway, 1998). In terms of the goodness-of-fit indices, the $\chi^{2} / d f$ ratio for most of the measurement models, except for the structural model, fell in the $2-5$ range, which is indicative of acceptable fit (Kelloway, 1998). Ratios less than 2 have been interpreted as indicating over-fitting. According to this standard interpretation, the model could either be seen to fit the data well or be seen to have been over-fitted. However, as recommended by Kelloway (1998), it is important not to rely solely on the $\chi^{2} / d f$ ratio, but to rather take into account a range of indices. The RMSEA suggested that the measurement and structural models fit the obtained data adequately (.024 to .0783), as values under .08 represent good model fit. The $p$-value for test of close fit (RMSEA <.05) varied between .053 and .695; the null hypothesis of close fit was therefore not rejected and the SLQ, OCBS and TEQ measurement models can be said to show close fit. The standardised RMR values of .009 to .06 are indicative of good model fit $(<.05)$ although the value for the OCBS marginally misses the .05 
level. The GFI values for the TEQ measurement and the structural models are close to 1 (.90 to .99), indicating that the values show good fit, as each scale is greater than .90 , the level required to indicate good fit. However, for the SLQ and the OCBS measurement models, the GFI value of .82 and .87 respectively fell marginally below the good fit level.

The results of the incremental fit measures indicated that, when compared to a baseline model, all three refined measurement models achieved NFI, NNFI, CFI, IFI and RFI indices of over 0.90, which represents good fit (Hair et al., 2006; Kelloway, 1998). These relative indices therefore appear to portray a positive picture of model fit.

\section{Measurement models: Factor loadings}

Table 2 presents a summary of the completely standardised factor loadings obtained for each of the refined measurement models. Except for two items, the completely standardised factor loading for the rest of the items comprising the measurement model exceeded the 0.50 level (Hair et al., 2006). This means that the items, in general, appeared to significantly reflect the dimension they were designed to represent.

\section{Item analysis}

Table 2 provides the reliability scores for each of the refined measuring scales. High levels of reliability were found for most of the subscales $(\alpha>0.70)$ except for most of the OCBS subscales (Nunnally, 1978). Satisfactory reliabilities were also found for the total SLQ $(\alpha=0.97)$, total OCBS $(\alpha=0.83)$ and total TEQ $(\alpha=0.89)$.

\section{The relationship between servant leadership and team effectiveness}

The rationale of evaluating the structural model through SEM was to determine whether the implied covariance matrix in the form of theoretical relationships specified at the conceptualisation stage were substantiated by the observed covariance matrix in the form of the data. The hypothesised relationship between servant leadership and team effectiveness was confirmed $(t=10.23, p<.05)$ (see Table 3). Thus, Hypothesis 1 was supported.

\section{The relationship between servant leadership and OCB}

A significant positive relationship was found between servant leadership and OCB $(t=4.85, p<.05)$. Thus, Hypothesis 2 was confirmed (see Table 3 ).

\section{The relationship between OCB and team effectiveness}

A significant positive relationship was found between OCB and team effectiveness. Therefore, Hypothesis 3 was supported $(t=4.40, p>.05)$ (See Table 3$)$.

\section{Discussion}

The study explored the relationships between servant leadership, organisational citizenship behaviour and team effectiveness. This was achieved through the testing of a structural model that explains the structural relationships hypothesised to exist amongst the constructs. The subobjectives involved testing the model's fit with data and evaluating the significance of the hypothesised paths in the model. The practical value of the results lies in the new

TABLE 1: Goodness-of-fit indices obtained for the refined SLQ, OCBS and TEQ measurement and structural models.

\begin{tabular}{llllllllll}
\hline Model & S-B $\chi^{2} / d f$ & RMSEA & $\mathbf{p}_{\text {close fit }}$ & SRMR & GFI & NFI & NNFI & CFI & IFI \\
\hline SLQ & 2.88 & .057 & .10 & .045 & .86 & .98 & .99 & .99 & .99 \\
OCBS & 2.19 & .048 & .65 & .06 & .87 & .94 & .97 & .97 & .97 \\
TEQ & 2.76 & .0783 & .0528 & .0455 & .95 & .97 & .97 & .97 & .93 \\
SMODEL & 1.50 & .024 & .695 & .009 & .991 & .995 & .998 & .999 & .99 \\
\hline
\end{tabular}

S-B $\chi^{2} / d f$, Satorra-Bentler scaled Chi-square/ degrees of freedom; RMSEA, root mean square error of approximation; $p$, $p$-value for test of close fit (RMSEA < 0.05 ); SRMR, standardised root mean residual; GFI, goodness-of-fit index; NFI, normed fit index; NNFI, non-normed fit index; CFI, comparative fit index; IFI; incremental fit index; RFI, relative fit index; SLQ, servant leadership mean residual; $\mathrm{GFI}$, goodness-of-fit index; $\mathrm{NFI}$, normed fit index; $\mathrm{NNFI,} \mathrm{non-normed} \mathrm{fit} \mathrm{index;} \mathrm{CFI}$, comparative fit index; IFl; incremen
questionnaire; OCBS, organisational citizenship behaviour scale; TEQ, Team effectiveness questionnaire; SMODEL, structural model.

\begin{tabular}{|c|c|c|c|c|}
\hline Scale & Variable & Number of items & CFA factor loadings & Cronbach's alpha $(\alpha)$ \\
\hline \multirow[t]{5}{*}{ SLQ } & Altruistic calling & 4 & $.80-.92$ & .92 \\
\hline & Emotional healing & 3 & $.88-.92$ & .94 \\
\hline & Wisdom & 5 & $.80-.91$ & .93 \\
\hline & Persuasive mapping & 4 & $.74-.86$ & .89 \\
\hline & Organisational stewardship & 5 & $.79-.89$ & .89 \\
\hline Total & - & 21 & - & .97 \\
\hline \multirow[t]{5}{*}{ OCBS } & Altruism & 5 & $.53-.77$ & .77 \\
\hline & Conscientiousness & 5 & $.56-.70$ & .67 \\
\hline & Sportsmanship & 5 & $.42-.72$ & .69 \\
\hline & Courtesy & 5 & $.51-.70$ & .58 \\
\hline & Civic virtue & 4 & $.53-.65$ & .55 \\
\hline Total & - & 24 & - & .83 \\
\hline TEQ & Team member effectiveness & 6 & $.48-.84$ & .79 \\
\hline Total & - & 10 & - & .88 \\
\hline
\end{tabular}

CFA, confirmatory factor analysis; SLQ, servant leadership questionnaire; OCBS, organisational citizenship behaviour scale; TEQ, team effectiveness questionnaire. 
TABLE 3: The gamma and beta matrix of path coefficients for the structural model.

\begin{tabular}{lll}
\hline Dimension & Servant leadership & Team effectiveness \\
\hline Organisational citizenship & .32 & .19 \\
behaviour & $(.07)$ & $(.06)$ \\
& $4.85^{*}$ & $4.40^{*}$ \\
Team effectiveness & .69 & - \\
& $(.06)$ & - \\
& $10.23^{*}$ & - \\
\hline
\end{tabular}

Note: Completely standardised path coefficients in bold; standard error estimates in brackets; $t$-values $\geq|1.96|$ indicate significant parameter estimates.

$*, p<.05$

knowledge gained with respect to the essential role played by the principal's servant leadership in affecting school team (teachers) behaviour.

Overall, the goodness-of-fit indices suggest that both the refined measurement and structural models produced good to reasonable fit. The theoretical model underlying each of the latent variables used in the current study was confirmed through confirmatory factor analysis. Therefore, it can be concluded that the items measured the latent variables as postulated by the instrument developers.

The significant relationship observed between servant leadership and team effectiveness (Hypothesis 2; $t=10.23$; $p<0.05)$ suggests that principals who embrace and practise the servant leadership style are likely to contribute to the overall school team effectiveness. This is expected as servant leaders view the development of followers as their ultimate goal rather than a means to reach the leader's or organisation's goals. The servant leader (principal) influences team effectiveness through the establishment of a favourable work climate that generates feelings of employee empowerment (Liden et al., 2008). These findings are in agreement with the findings of $\mathrm{Hu}$ and Liden (2011), Irving and Longbotham (2007) and Transcritti (2010), who reported a similar relationship between the two constructs.

Servant leadership has a significant positive relationship with organisational citizenship behaviour (Hypothesis 3; $t=4.85 ; p<0.05)$. This concurs with findings in previous studies that documented the positive influence of supportive and value-based leadership styles on citizenship behaviour (e.g. Alizadeh et al., 2012; Davoudi, 2012; LePine, Erez \& Johnson, 2002; Podsakoff et al., 2000; Schlecter \& Engelbrecht, 2006). Principals as servant leaders, like those who employ other value-based leadership styles, can shape the school work climate to provide greater opportunities for the enactment of behaviours that are likely to promote positive behaviours such as OCB. It would be hard for a teacher to exhibit extra-role behaviours when the teacher detests the leadership style of the principal.

The relationship between organisational citizenship behaviour and team effectiveness (Hypothesis 4) was also corroborated $(t=4.40 ; p<0.05)$. This supports the findings by Karambayya (1990) and Ren-Tao and Heung-Gil (2009), who concluded that high-performance teams are made up of employees who exhibit high organisational citizenship behaviour. According to Podsakoff and MacKenzie (1997), the presence of OCB in an organisation can increase effectiveness through mechanisms such as increased managerial and coworker productivity, more effective use of scarce resources or increased organisational flexibility. Successful teams in schools need teachers who will perform beyond their usual job duties and provide academic performance that is beyond expectations.

\section{Limitations and suggestions for future research}

One of the limitations of the study relates to the comparability of a service-oriented context to a business-oriented setting. The study was conducted in a school setting, which is usually service-oriented, whilst business settings are revenue-generating. Thus, future studies should examine whether service-oriented and revenue-generating teams are comparable. Additionally, the treatment of each school as a team had its own limitation. A typical school team of teachers is composed of the foundation phase, intermediate and senior phase teams. The functioning of these sub-teams may be different from how the broader school team operates; foundation phase teachers might work together much more efficiently than those in the intermediate phase.

Future studies should attempt to draw probability samples from other schools in order to increase the demographic representativeness of the teacher population in the Western Cape and South Africa.

Future research should expand the theoretical model by incorporating other latent variables, such as trust, emotional intelligence, organisational justice and psychological empowerment, to explain additional variance in team effectiveness.

Collecting research data concurrently rather than longitudinally may have caused same-source or common method biases. Podsakoff and MacKenzie (1994) have argued that a longitudinal design could reduce this potential influence (see Mahembe \& Engelbrecht, 2013). They state two further advantages that a longitudinal study would have over cross-sectional studies, namely:

- It would permit better assessment of the causal priority of servant leadership, OCB, and team effectiveness.

- It would allow examination of the longer-term effects of servant leadership and OCB on team effectiveness.

\section{Managerial implications}

The current study reported positive relationships between servant leadership and team effectiveness, servant leadership and OCB and OCB and team effectiveness. The findings imply that school principals should focus on increasing school team effectiveness through the utilisation of the servant leadership style. A principal's servant leadership is likely to promote teacher development as it enables the principal to coach teachers as well as nurture their talents 
to levels that ultimately influence the overall school team effectiveness. In view of the heterogeneous nature of the South African population, workplace teams are likely to be made up of teachers from diverse backgrounds in terms of race, culture, language and, in some cases, nationality. Failure to understand individual differences is likely to have negative repercussions for the school. The principal as servant leader is likely to provide some coaching, coordination and development to the teachers to increase their understanding of individual differences. Hence, the increase in OCBs and school team effectiveness can also be an indirect measure of the ability to work together despite individual differences and a good reflection of the underlying leadership style of the principal.

\section{Conclusion}

Successful school teams need teachers who go beyond their usual job duties and provide academic performance that is beyond expectations. In order to reach this ideal, school teams need leaders who place greater emphasis on teacher development and are more inclined to serve, empower and recognise the talents of others than to advance their own needs. Servant leadership has shown some promise and positions itself as the ideal leadership style for team effectiveness. If principals humbly avail their service to their school teams, recognise and nurture the teachers' talents, then the teachers are likely to go the extra mile and ultimately help the school achieve effectiveness by cooperating with other teachers, taking initiative and participating in various school activities. To achieve a high level of OCB and team effectiveness in schools, school principals are required to perform activities of servant leadership such as supporting and developing teachers, respecting teachers, providing a trustable, moral and respectful environment and caring for teachers.

\section{Acknowledgements Competing interests}

The authors declare that they have no financial or personal relationships that may have inappropriately influenced them in writing this article.

\section{Authors' contributions}

B.M. (Stellenbosch University) was the project leader responsible for the data collection, statistical analyses and write-up of the article, whilst A.S.E. (Stellenbosch University) contributed to the refinement of the measures, as well as to the write-up of the article.

\section{References}

Afolabi, O.A., Adesina, A., \& Aigbedion, A. (2009). Influence of team leadership and team commitment on teamwork and conscientiousness. Journal of Social Sciences, 21(3), 211-216.

Alizadeh, Z., Darvishi, S., Nazari, K., \& Emami, M. (2012). Antecedents and consequences of organisational citizenship behaviour (OCB). Interdisciplinary Journal of Contemporary Research in Business, 3(9), 494-505.
Barbuto, J.E., \& Wheeler, D.W. (2006). Scale development and construct clarification of servant leadership. Group and Organisational Management, 31(3), 300-326. http://dx.doi.org/10.1177/1059601106287091

Bettenhausen, K.L. (1991). Five years of group research: What we have learnt and what needs to be addressed. Journal of Management, 17, 345-381. http://dx.doi. org/10.1177/014920639101700205

Bush, T., \& Heystek, J. (2006). School Leadership and Management in South Africa: Principals' perceptions. Educational Management and Professional Development, 34(3), 63-76.

Cerit, Y. (2009). The effects of servant leadership behaviours of school principals on teachers' job satisfaction. Educational Management Administration \& Leadership 37(5), 600-623. http://dx.doi.org/10.1177/1741143209339650

Cohen, S., \& Bailey, D. (1997). What makes teams work: Group effectiveness research from the shop floor to the executive suite? Journal of Management, 3, 239-290. http://dx.doi.org/10.1177/014920639702300303

Dannhauser, Z. (2007). Relationship between servant leadership, follower trust, team commitment and unit effectiveness. Unpublished doctoral dissertation, University of Stellenbosch, South Africa.

Dannhauser, Z., \& Boshoff, A.B. (2007). Structural equivalence of the Barbuto and Wheeler (2006) Servant Leadership Questionnaire on North American and South African samples. International Journal of Leadership Studies, 2, 148-168.

Davoudi, S.M.M. (2012). A comprehensive study of organizational citizenship behavior (OCB): Introducing the term, clarifying its consequences and identifying its antecedents. Journal of Economics and Management, 1(2), 73-85.

Diamantopoulos, A., \& Siguaw, J.A. (2000). Introducing LISREL. London: Sage.

DuFour, R. (2001). In the right context. Journal of Staff Development, 22(1), 14-17.

Ehrhart, M.G. (2004). Leadership and procedural justice climate as antecedents of unit-level organizational citizenship behaviour. Personnel Psychology, 57, 61-94. http://dx.doi.org/10.1111/j.1744-6570.2004.tb02484.x

Gladstein, D. (1984). Groups in context: A model of task group effectiveness. Administrative Science Quarterly, 29, 499-517. http://dx.doi.org/10.2307/2392936

Graham, J. (1991). Servant leadership in organisations: Inspirational and moral. Leadership Quarterly, 2(2), 105-119. http://dx.doi.org/10.1016/1048-9843(91)90025-W

Greenleaf, R. (1970). The servant as leader. Indianapolis: Robert K. Greenleaf Center.

Greenleaf, R. (1977). Servant leadership: A journey into the nature of legitimate power and greatness. New York: Paulist Press.

Güçel, C., \& Begeç, S. (2012). The effect of the servant leadership on organizational citizenship behaviour: Case study of a university. International Journal of Social Sciences and Humanity Studies, 4(1), 107-116.

Gupta, V., Huang, R., \& Niranjan, S. (2010). A longitudinal examination of the relationship between team leadership and performance. Journal of Leadership \& Organizational Studies, 17, 335-350. http://dx.doi.org/10.1177/ 1548051809359184

Guzzo R. (1986). Group decision making and group effectiveness. In P.S. Goodman (Ed.), Designing Effective Work Groups (pp. 34-71). San Francisco: Jossey Bass.

Hackman J. (1987). The design of work teams. In J.W. Lorsch (Ed.), Handbook of organisational behaviour (pp. 315-342). Englewood Cliffs, NY: Prentice-Hall.

Hackman, J.R. (2002). Leading teams: Setting the stage for great performances. Boston: Harvard Business School Press.

Hackman, J.R., \& Walton, R.E. (1986). Leading groups in organisations. In P.S. Goodman \& Associates (Eds.), Designing effective work groups (pp. 72-119). San Francisco: Jossey-Bass.

Hair, J.F., Black, W.C., Babin, B.J., \& Anderson, R.E. (2010). Multivariate data analysis: A global perspective. (7th edn.). Upper Saddle River, NJ: Pearson. http://dx.doi. org/10.1016/j.jmva.2009.12.014

Hallinger, P., \& Heck, R.H. (1996). Reassessing the principal's role in school effectiveness: A Review of the empirical research. Educational Administration Quarterly 32(1), 27-31. http://dx.doi.org/10.1177/0013161X96032001002

$\mathrm{Hu}$, J., \& Liden, R. C. (2011). Antecedents of team potency and team effectiveness: An examination of goal and process clarity and servant leadership. Journal of Applied Psychology, 96(4), 851-862. http://dx.doi.org/10.1037/a0022465

Hui, C., Law, K.S., \& Chen, Z.X. (1999). A structural equation model of the effects of negative affectivity, leader-member exchange and perceived job mobility on in-role and extra-role performance: A Chinese case. Organisational Behaviour and Human Decision Processes, 77(1), 3-21. http://dx.doi.org/10.1006/ obhd.1998.2812

Irving, J.A., \& Longbotham, G.J. (2007). Team effectiveness and six essential servant leadership themes: A regression model based on items in the Organizational Leadership Assessment. International Journal of Leadership Studies, 2(2), 98-113.

Jöreskog, K.G., \& Sörbom, D. (1996). LISREL 8: User's reference guide. Chicago: Scientific Software International. PMid:9010656.

Jöreskog, K.G., \& Sörbom, D. (2006). Interactive LISREL 8.80. Chicago: Scientific Software International.

Karambayya, R. (1990). Good organizational citizens do make a difference. Proceedings of the Administrative Sciences Association of Canada (pp. 110-119). Whistler British Columbia: The Administrative Sciences of Canada.

Katz, D. (1964). Motivational basis of organisational behaviour. Behavioural Science, 9(2), 131-146. http://dx.doi.org/10.1002/bs.3830090206 
Kelloway, E.K. (1998). Using LISREL for structural equation modelling: A researcher's guide. USA: Sage.

Kolodny, H.F., \& Kiggundu, M.N. (1980). Towards the development of a sociotechnical systems model in woodlands mechanical harvesting. Human Relations, 33, 623645. http://dx.doi.org/10.1177/001872678003300902

Kozlowski, S.W.J., \& Ilgen, D.R. (2006). Enhancing the effectiveness of work groups and teams. Psychological Science in the Public Interest, December, 1-119.

Kuo, C.C. (2004). Research on impacts of team leadership on team effectiveness Journal of American Academy of Business, 5(1), 266-277.

Larson, C.E., \& LaFasto, F.M.J. (2001). The team effectiveness questionnaire. In P.G. Northouse, Leadership: Theory and practice (2nd edn.) (p. 184). Thousand Oaks, CA: Sage.

LePine, J.A., Erez, A., \& Johnson, D.E. (2002). The nature and dimensionality of organisational citizenship behaviour. A critical review and meta-analysis. Journal of Applied Psychology, 87(1), 52-65. http://dx.doi.org/10.1037/0021-9010.87.1.52

Liden, R.C., Wayne, S.J., Zhao, H., \& Henderson, D. (2008). Servant leadership: Development of a multidimensional measure and multi-level assessment. Leadership Quarterly, 19, 161-177. http://dx.doi.org/10.1016/j.leaqua.2008.01.006

Lord, R.G., Brown, D.J., \& Freiberg, S.J. (1999). Understanding the dynamics of leadership: The role of follower self-concepts in the leader/follower relationship. Organizational Behaviour and Human Decision Processes, 78(3), 167-203. http:// Organizational Behaviour and Human

Luthans, F., \& Avolio, B. (2003). Authentic leadership: A positive development approach. In K.S. Cameron, J.E. Dutton, \& R.E. Quinn (Eds.), Positive organizational scholarship: Foundations of a new discipline (pp. 241-261). San Francisco: BerrettKoehler.

Mahembe, B., \& Engelbrecht, A.S. (2013). The relationship between servant leadership, affective team commitment and team effectiveness. SA Journal of Human ResourceManagement/SA Tydskrif vir Menslikehulpbronbestuur, 11(1) Art. \#495, 10 pages. http://dx.doi.org/10.4102/sajhrm.v11i1.495

McCrimmon, M. (2010). Servant leadership. Retrieved January 25, 2012, from http:// www.leadersdirect.com/servantleadership

McGrath, J.E. (1964). Toward a 'theory of method' for research on organizations. In W.W. Cooper, L. Leavitt, \& M.W. Shelley (Eds.), New perspectives in organization research (pp. 533-547). New York: John Wiley.

Mels, G. (2003). A workshop on structural equation modelling with LISREL 8.54 for Windows. University of Port Elizabeth.

Mohammad, J., Habib, F.Q., \& Alias, M.A. (2011). Job satisfaction and organisational citizenship behaviour: An empirical study at higher learning institutions. Asian Academy of Management Journal, 16(2), 149-165.

Moorman, R.H. (1991). Relationship between organisational justice and organisational citizenship behaviours: Do fairness perceptions influence employee citizenship? Journal of Applied Psychology, 76(6), 845-855. http://dx.doi.org/10.1037/0021 Journal of Applier

Morgeson, F.P., DeRue, D.S., \& Karam, E.P. (2010). Leadership in teams: A functional approach to understanding leadership structures and processes. Journal of Management, 36(1), 5-39. http://dx.doi.org/10.1177/0149206309347376

Neale, M., \& Mannix, E. (2012). Research on managing groups and teams. In M.A. Neale, \& E.A. Mannix (Eds.), Looking back, moving forward: A review of group and team-based research (research on managing groups and teams), Vol. 15 (pp. 359-381). Bingley, UK: Emerald Group Publishing.

Neubert, M.J., Kacmar, K.M., Carlson, D.S., Chonko, L.B., \& Roberts, J.A. (2008) Regulatory focus as a mediator of the influence of initiating structure and servant leadership on employee behavior. Journal of Applied Psychology, 93, 1220-1233. http://dx.doi.org/10.1037/a0012695

Niehoff, B.P., \& Moorman, R.H. (1993). Justice as a mediator of the relationship between methods of monitoring and organisational citizenship behaviour. Academy of Management Journal, 36(3), 527-556. http://dx.doi.org/10.2307/256591

Nieva, V.F., Fleishman, E.A., \& Reick, A. (1978). Team dimensions: Their identity, their measurement, and their relationships. Final Technical Report. Contract No. DAH19-78-C- 0001. Washington, DC: Advanced Research Resources Organisation.

Nunnally, J.C. (1978). Psychometric theory. New York: McGraw-Hill.

Organ, D.W. (1988). Organisational citizenship behaviour: The good soldier syndrome. Lexington, MA: Lexington Books.

Parolini, J., Patterson, K., \& Winston, B. (2009). Distinguishing between transformationa and servant leadership. Leadership and Organization Development Journal, 30(3) 274-291. http://dx.doi.org/10.1108/01437730910949544

Piccoli, G., Powell, A., \& Ives, B. (2004). Virtual teams: Team control structure, work processes, and team effectiveness. Information Technology and People, 17, 359processes, and team effectiveness. Information Techn
379. http://dx.doi.org/10.1108/09593840410570258

Pina, M., Martinez, A., \& Martinez, L. (2008). Teams in organizations: A review on team effectiveness. Team Performance Management, 14(1/2), 7-21. http:// dx.doi.org/10.1108/13527590810860177

Podsakoff, P.M., \& MacKenzie, S.B. (1994). An examination of the psychometric properties and nomological validity of some revised and reduced 'substitutes for leadership' scales. Journal of Applied Psychology, 79(5), 702-713. http://dx.doi. org/10.1037/0021-9010.79.5.702

Podsakoff, P.M., \& Mackenzie, S.B. (1997). Impact of organisational citizenship behaviour on performance: A review and suggestions for further research. Human Performance, 10(2), 133-151. http://dx.doi.org/10.1207/s15327043hup1002 5
Podsakoff, P.M., MacKenzie, S.B., Paine, J.B., \& Bachrach, D.G. (2000). Organisational citizenship behaviours: A critical review of the theoretical and empirical literature
and suggestions for future research. Journal of Management, 26, 513-563. http:// and suggestions for future research. Journal
dx.doi.org/10.1177/014920630002600307

Randel, A.E. (2003). The salience of culture in multinational teams and its relation to team citizenship behaviour. International Journal of Cross Cultural Management 3(1), 27-44. http://dx.doi.org/10.1177/1470595803003001848

Ren-Tao, M., \& Heung-Gil, K. (2009). The impact of organisational citizenship behaviour on team effectiveness in China: The moderating role of task complexity. Fourth International Conference on Computer Sciences and Convergence Information Technology (pp. 641-646). Seoul: Institute of Electrical and Electronic Engineers.

Ross, T.M., Jones, E.C., \& Adams, S.G. (2008). Can team effectiveness be predicted? Team Performance Management, 14(5/6), 248-268. http://dx.doi. org/10.1108/13527590810898518

Rowan, L., Knobel, M., Bigum, C., \& Lankshear, C. (2002). Boys, literacies and schooling Buckingham: Open University Press.

Salas, E., Dickenson, T.L., Converse, S.A., \& Tannenbaum, S.I. (1992). Toward an understanding of team performance and training. In R.J. Swezey \& E. Salas (Eds.), Teams: Their training and performance (pp. 3-29). Norwood, NJ: Ablex.

Salas, E., Stagl, K.C., \& Burke, C.S. (2004). 25 years of team effectiveness in organizations: Research themes and emerging needs. In C.L. Cooper, \& I. T. Robertson (Eds.) International Review of Industrial and Organizational Psychology, Vol. 19 (pp. 47-91). Chichester: John Wiley.

Schlechter, A.F., \& Engelbrecht, A.S. (2006). The relationship between transformational leadership, meaning and organisational citizenship behaviour. Managemen Dynamics: Journal of the South African Institute for Management Scientists, 15(4), 2-16.

Schlechter, A.F., \& Strauss, J.J. (2008). Leader emotional intelligence, transformational leadership, trust and team commitment: Testing a model within a team context. South African Journal of Industrial Psychology, 34(1), 42-53.

Sendjaya, S., \& Sarros, J.C. (2002). Servant leadership: Its origin, development, and application in organisations. Journal of Leadership \& Organisational Studies, 9(2), 57-65.

Sendjaya, S., Sarros, J.C., \& Santorra, J.C. (2008). Defining and measuring servant leadership behaviour in organisations. Journal of Management Studies, 45(2), 402-424.

Shea, G.P., \& Guzzo, R.A. (1987). Group effectiveness: What really matters? Sloan Management Review, 28, 25-31

Sheng, C., \& Tian, Y. (2010). Relationships among teamwork behaviour, trust, perceived team support, and team commitment. Social Behaviour and Personality, 38(10), 1297-1306. http://dx.doi.org/10.2224/sbp.2010.38.10.1297

Sisman, M. (2004) Ög retim Liderlig $i$ [Instructional Leadership]. Ankara: PegemA Publication.

Stagl, K.C., Salas, E., \& Burke, C.S. (2007). Best practices in team leadership: What team leaders do to facilitate team effectiveness. In J.A. Conger \& R.E. Riggio (Eds.), The practice of leadership: Developing the next generation of leaders (pp. 172The practice of leadership: Develop
198). San Francisco: Jossey-Bass.

Sun, J.M. \& Wang, B. (2009). Servant leadership in China: Conceptualization and measurement. Advances in Global Leadership, 5, 321-344. http://dx.doi. measurement. Advances in Global Leaders

Transcritti, F.G. (2010). The relationship between servant leadership and team effectiveness of deacon ministries in Southern Baptist churches. Unpublished PhD thesis, The Southern Baptist Theological Seminary, Louisville, KY.

Van Dierendonck, D. (2011). Servant leadership: A review and synthesis. Journal of Management, 37(4), 1228-1261. http://dx.doi.org/10.1177/0149206310380462

Van Dierendonck, D., \& Nuijten, I. (2011). The servant-leadership survey (SLS): Development and validation of a multidimensional measure. Journal of Business and Psychology, 26(3), 249-267. http://dx.doi.org/10.1007/s10869-010-9194-1

Vondey, M. (2010). The relationships among servant leadership, organizationa citizenship behaviour, person-organization fit, and
International Journal of Leadership Studies, 6(1), 3-27.

Walumbwa, F.O., Hartnell, C.A., \& Oke, A. (2010). Servant leadership, procedura justice climate, service climate, employee attitudes, and organisational citizenship behaviour: A cross-level investigation. Journal of Applied Psychology, 95(3), 517529. http://dx.doi.org/10.1037/a0018867

Williams, L.J., \& Anderson, S.E. (1991). Job satisfaction and organisational commitment as predictors of organisational citizenship behaviour and inrole behaviours. Journal of Management, 17(3), 601-617. http://dx.doi. org/10.1177/014920639101700305

Witt, L.A. (1991). Exchange ideology as a moderator of job attitudes-organisational citizenship behaviours relationship. Journal of Applied Social Psychology, 21(18) 1490-1501. http://dx.doi.org/10.1111/j.1559-1816.1991.tb00483.x

Wong, A., Tjosvold, D., \& Liu, C. (2009). Cross-functional team organisational citizenship behaviour in China: Shared vision and goal interdependence amon departments. Journal of Applied Social Psychology, 39(12), 2879-2909. http:// dx.doi.org/10.1111/j.1559-1816.2009.00554.x

Zhu, W., May, D.R., \& Avolio, B.J. (2004). The impact of ethical leadership behaviour on employee outcomes: The roles of psychological empowerment and authenticity. Journal of Leadership \& Organisational Studies, 11(1), 16-26. http://dx.doi. org/10.1177/107179190401100104 